\title{
PHYLOGENETICS OF THE SUBTRIBE PLEUROTHALLIDINAE (EPIDENDREAE: ORCHIDACEAE) BASED ON COMBINED EVIDENCE FROM DNA SEQUENCES
}

\author{
Alec M. Pridgeon \& Mark W. Chase \\ Royal Botanic Gardens, Kew, Richmond, Surrey TW9 3AB, UK
}

Subtribe Pleurothallidinae (Epidendreae: Orchidaceae) comprises an estimated 4000 Neotropical species in about 30 genera (Luer 1986), accounting for $15-20 \%$ of the species in the entire family. The vast majority are dipteran-, deceit-pollinated epiphytes with sympodial growth, unifoliate nonpseudobulbous stems or "ramicauls," conduplicate leaves, velamentous roots, and an articulation between the pedicel and ovary. Genera have been circumscribed on the basis of number of pollinia- eight, six, four or two - although there can be either eight or six in Brachionidium Lindl. (Luer 1986) and two or four (one large pair and one small pair) in Myoxanthus Poepp. \& Endl. and Lepanthes Sw. (Stenzel 2000).

To evaluate the monophyly of subtribe Pleurothallidinae (Epidendreae: Orchidaceae) and the component genera and to reveal evolutionary relationships and trends, we sequenced the nuclear ribosomal DNA internal transcribed spacers (ITS1 and ITS2) and 5.8S gene for 185 taxa (Pridgeon, Solano \& Chase 2001), later increased to 187 taxa (Pridgeon \& Chase 2001). Dilomilis montana, Neocogniauxia hexaptera, Arpophyllum giganteum, and Isochilus amparoanus were used as outgroups. All but seven of the 32 subgenera of the megagenus Pleurothallis are represented by one or more taxa; those subgenera not represented are monospecific or comprise only a few species. As a result, the overall morphological diversity was sampled to minimize spurious attractions, a strategy recommended for large study groups in particular (Hillis 1998).

To resolve internal nodes in the ITS topology and offer additional evidence from another genome, we also sequenced the plastid gene matK and the trnL intron with the $t r n L-F$ intergenic spacer (hereafter simply trnL-F) for a representative subset of the taxa in the ITS study (Pridgeon, Solano \& Chase 2001, Pridgeon \& Chase 2001). Sequences of $r b c L$ (Chase et al. 1994, Kores et al. 1997, Cameron et al. 1999, van den Berg 2000), matK (Ryan et al. 2000, van den Berg 2000, Kores et al. 2001; Whitten, Williams \& Chase 2000), and trnL-F (van den Berg 2000, Kores et al. 2001, Whitten, Williams \& Chase 2000) have been useful in evaluating higher-level relationships in Orchidaceae by virtue of the relatively conservative evolution of the plastid genome.

Finally, we combined the plastid data with the corresponding ITS sequences for a separate analysis of 58 representative taxa to assess congruence among the separate and combined data sets (Pridgeon, Solano \& Chase 2001, Pridgeon \& Chase 2001). In this way we were able to compare topologies of DNA regions with different functional constraints (e.g., coding vs. noncoding, nuclear vs. plastid, concerted evolution in ribosomal ITS sequences) before combining them to limit spurious results in the separate analyses (Johnson \& Soltis 1998, Soltis, Soltis and Chase 1999, Wiens 1998).

There is strong support in most analyses (Pridgeon, Solano \& Chase 2001, Pridgeon \& Chase 2001) for the monophyly of Pleurothallidinae and, as in other analyses (van den Berg et al. 2000), for inclusion of Dilomilis and Neocognauxia in Pleurothallidinae. Taking into account the highly supported molecular evidence from multiple DNA regions, the shared number of pollinia in some taxa (eight) and leaf anatomy, the ancestral reed-stem condition in other clades of Epidendroideae (van den Berg 2000), and evolutionary remnants thereof in present-day Pleurothallidinae, we proposed (Pridgeon \& Chase, 2001) that Pleurothallidinae be expanded to include Dilomilis, Neocogniauxia, and presumably the monospecific Tomzanonia, thereby forming a more natural 
unit. Furthermore, recognition of a new subtribe comprising only three genera that are collectively sister to Pleurothallidinae would result in unnecessary taxonomic inflation.

Although most genera in the several clades identified in the analyses are monophyletic, all data sets are highly congruent in revealing the polyphyly of Pleurothallis and its constituent subgenera as presently understood, falling into seven clades with generally strong bootstrap support (Pridgeon, Solano \& Chase, 2001, Pridgeon \& Chase, 2001). The high degree of homoplasy in anatomical/morphological characters, especially floral characters, limits their usefulness in phylogenetic reconstruction of the subtribe.

\section{Literature Cited}

Cameron, K.M., M.W. Chase, W.M. Whitten, P.J. Kores, D.C. Jarrell, V.A. Albert, T. Yukawa, H.G. Hills and D.H. Goldman. 1999. A phylogenetic analysis of the Orchidaceae: evidence from $r b c L$ nucleotide sequences. Amer. J. Bot. 86: 208-224.

Chase, M.W., K.M. Cameron, H.G. Hills and D. Jarrell. 1994. DNA sequences and phylogenetics of the Orchidaceae and other lilioid monocots. In A. M. Pridgeon (ed.), Proceedings of the 14th World Orchid Conference, 61-73. HMSO, Edinburgh, UK.

Hillis, D.M. 1998. Taxonomic sampling, phylogenetic accuracy, and investigator bias. Syst. Biol. 47: 3-8.

Johnson, L.A. and D.E. Soltis. 1995. Phylogenetic inference in Saxifragaceae sensu stricto and Gilia (Polemoniaceae) using matK sequences. Ann. Missouri Bot. Gard. 82: 149-175.

Kores, P.J., K.M. Cameron, M. Molvray and M.W. Chase. 1997. The phylogenetic relationships of Orchidoideae and Spiranthoideae (Orchidaceae) as inferred from $r b c L$ plastid sequences. Lindleyana 12: 1-11.
Kores, P.J., M. Molvray, S.D. Hopper, P.H. Weston, A.P. Brown, K.M. Cameron and M.W. Chase. 2001. A phylogenetic analysis of Diurideae (Orchidaceae) based on plastid DNA sequence data. Amer. J. Bot. 88: 19031914.

Luer, C.A. 1986. Icones Pleurothallidinarum I. Systematics of the Pleurothallidinae (Orchidaceae). Monogr. Syst. Bot. Missouri Bot. Gard. 15.

Pridgeon, A.M., R. Solano and M.W. Chase. 2001. Phylogenetic relationships in Pleurothallidinae (Orchidaceae): combined evidence from nuclear and plastid DNA sequences. Amer. J. Bot. 88: 2286-2308.

Pridgeon, A.M. and M.W. Chase. 2001. A phylogenetic reclassification of Pleurothallidinae (Orchidaceae). Lindleyana 16: 235-271.

Ryan, A., W.M. Whitten, M.A. T. Johnson and M.W. Chase. 2000. A phylogenetic assessment of Lycaste and Anguloa (Orchidaceae: Maxillarieae). Lindleyana 15: 33-45.

Soltis, P.S., D.E. Soltis and M.W. Chase. 1999. Angiosperm phylogeny inferred from multiple genes as a tool for comparative biology. Nature 402: 402-404.

Stenzel, H. 2000. Pollen morphology of the subtribe Pleurothallidinae Lindl. (Orchidaceae). Grana 39: 108125 .

van den Berg, C. 2000. Molecular phylogenetics of tribe Epidendreae with emphasis on subtribe Laeliinae (Orchidaceae). Ph.D. thesis, University of Reading, UK. van den Berg, C., W.E. Higgins, R.L. Dressler, W.M. Whitten, M.A. Soto Arenas, A. Culham and M.W. Chase. 2000. A phylogenetic analysis of Laeliinae (Orchidaceae) based on sequence data from nuclear transcribed spacers (ITS) of ribosomal DNA. Lindleyana 15: 96-114.

Whitten, W.M., N.H. Williams and M.W. Chase. 2000. Subtribal and generic relationships of Maxillarieae (Orchidaceae) with emphasis on Stanhopeinae: combined molecular evidence. Amer. J. Bot. 87: 1842-1856.

Wiens, J.J. 1998. Combining data sets with different phylogenetic histories. Syst. Biol. 47: 568-581.

Alec M. Pridgeon was born in 1950 in Dallas, Texas, USA and received his Ph.D. in biology from Florida State University, specializing in anatomy and systematics of orchids. He is presently Sainsbury Orchid Fellow at the Royal Botanic Gardens, Kew, where he specializes in molecular phylogenetics and co-edits and contributes to Genera Orchidacearum, a comprehensive multi-volume monograph of the orchid family. Volumes 1-3 of Genera Orchidacearum have already been published by Oxford University Press, and Volume 4 is in preparation.

Mark W. Chase was born in 1951 and received his Ph.D. in systematic botany from the University of Michigan. His research interests include systematics and evolution of angiosperms, in particular Orchidaceae. He is currently Head of the Molecular Systematics Section at the Royal Botanic Gardens, Kew, and co-edits and contributes to Genera Orchidacearum. 